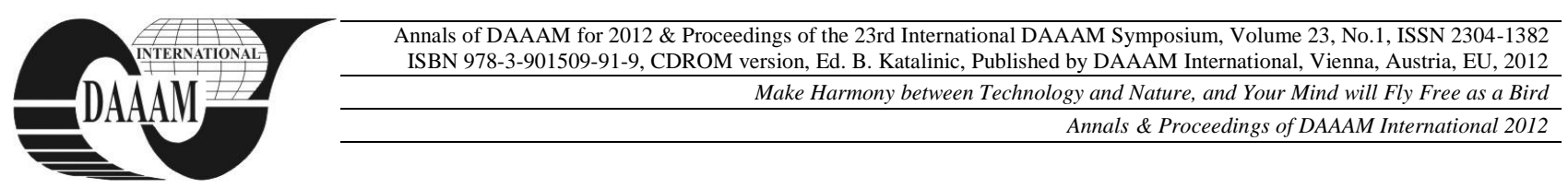

\title{
ALTERNATIVE ASSESSMENT OF THE ENTITY'S ABILITY TO CONTINUE THE ACTIVITY
}

\author{
SIMIONESCU, M[ircea]
}

\begin{abstract}
Some financial reporting frameworks contain an explicit requirement according to which the management must make an explicit assessment of the entity's ability to continue the activity. Management's evaluation regarding the Company's ability to continue the activity involves reasoning at some point in time, regarding future results, uncertain by their nature, of the events or conditions. Further on, the auditors should evaluate the management's assessment regarding the ability of the Company to continue the activity, taking into account the extent in which the management's assessment includes all relevant information of which the auditor is aware as a result of the audit. Finally, based on the audit evidence obtained, the auditor should conclude whether, according to his reasoning, there is a material uncertainty related to events or conditions that, individually or collectively, may cast significant doubt on the ability of the Company to continue the activity.

Keywords: Analysis, Audit, Continuity, Subsequent events
\end{abstract}

\section{INTRODUCTION}

International Standards of Audit no. 560, "Subsequent Events" and no. 570, "Going concern principle" implies objectives such as:

- Obtain sufficient appropriate audit evidence on whether the events that occur between the date of the financial statements and auditor's report date which implies adjustment of financial statements or a presentation are reflected properly in the financial statements in accordance with the general framework of financial reporting;

- Providing appropriate responses to the facts of which the auditor becomes aware after the auditor's report date, which, if it had been known to the auditor at that time, would have caused the auditor to modify his report;

- Obtain sufficient and appropriate audit evidence regarding the appropriateness of applying the going concern assumption by the management in preparing the financial statements;

- Develop an opinion based on the audit evidence obtained, the likelihood of material uncertainties related to future events or conditions that could give rise to significant doubt on the entity's ability to continue the activity.

Some financial reporting frameworks contain an explicit requirement according to which the management must make an explicit assessment of the entity's ability to continue the activity. There are also functional standards regarding the issues which must be taken into consideration and disclosures to be made about going concern (international Standard of audit no. 570 point 3 ). Management's evaluation regarding the Company's ability to continue the activity involves reasoning at some point in time, regarding future results, uncertain by their nature, of the events or conditions. Further on, the auditors should evaluate the management's assessment regarding the ability of the Company to continue the activity, taking into account the extent in which the management's assessment includes all relevant information of which the auditor is aware as a result of the audit. Finally, based on the audit evidence obtained, the auditor should conclude whether, according to his reasoning, there is a material uncertainty related to events or conditions that, individually or collectively, may cast significant doubt on the ability of the Company to continue the activity.

\section{CONTINUITY ISSUES IN DEVELOPING THE ACTIVITY}

When applying risk assessment procedures ordered by ISA $315^{3}$, the auditor is required to analyze to the extent to which there are events or conditions that could pose significant doubt on the entity's ability to continue the activity, following to what extent the management made a preliminary assessment of the entity in terms of its ability to continue the activity. Further on, it requires appreciation of this assessment which must cover at least twelve months from the date of the financial statements.

The following is a selection of financial indicators which can predict events or conditions that cast doubt on the assumption of continuity of the firm activity:

- Net debt or the position of net current debt Net accounts $=$ Active - Debts

Net accounts is most often positive and increasing, as a result of healthy economic management. This account marks reaching the major objective of financial management, namely maximizing the value of equity, net asset financed by these equities. Increasing the net account is the result of a portion of net profit and of other accumulation elements: provision regulated, reports from previous fiscal year, grants etc.

Net account may have, in pre-bankruptcy cases, negative value. This means an overcome of the real asset, by the total debt incurred by the company. Such net account is the consequence of closing with loss the previous fiscal year.

The amount of these losses has consumed entirely the equities, and the uncovered part remains in the creditors' task, as a result of assuming the risk of insolvency of the company.

Net account may indicate, therefore, an enrichment (increase in equity), in case of accomplishment and 
reinvestment of profits or, conversely, an impoverishment (a reduction of equity), in case of closing the fiscal year with losses.

- Fixed-term loans approaching maturity without realistic prospects of renewal or repayment;

- Excessive dependence on short-term loans to finance long-term assets;

- Negative operating cash flows indicated in the historical and projected financial statements;

- Unfavorable key financial indicators:

\subsection{Solvency rates:}

Patrimonial solvency rate (Equity / Total liabilities $x 100)$

It expresses the company's self-financing capacity, as well as the extent to which it can meet its payment obligations. A high value of this indicator signifies an increase in the company's self-financing capacity. Financial safety interval: higher than $30 \%$. x100)

Financial autonomy rate (equity / permanent capital

It expresses the company's financial independence. Equity increased share of the company in its permanent capital, has beneficial effects on total financial autonomy. Financial safety interval: higher than $50 \%$.

Overall indebtedness rate (total debt / equity $x$ 100) The indicator shows the proportion of total debt financing on behalf of the company equity. A reduction of this indicator level reflects a self-financing capacity on short, medium and long term. A superior level of $50 \%$ may result in a warning for company creditors.

Financial safety interval: less than $50 \%$.

Overall solvency rate (total debt / total assets $x$ 100) It expresses the extent to which a company's assets contribute to its overall debt.

Financial safety interval: less than $30 \%$.

\subsection{Rates of liquidity:}

Current or general liquidity rate (Current assets / Short term liabilities $x$ 100)

Production-oriented patrimonial entities have an operating cycle in which the inputs in production are obtained and processed into finished products and then sold and converted into cash (money). This requires an investment in working capital (trading capital), in other words, it takes financial resources to finance inventories and receivables-customers. Most of these funds come from commercial creditors and the remaining amount needed will be obtained from the initial capitalization, from bank loans and positive cash flow resulting from current operations. At any given time, patrimonial entity will have a certain situation of net working capital. This represents the amount by which current assets exceed short-term debt and is measured by overall liquidity. Basically, if net trading capital is positive (overall liquidity is greater than 1.0), the patrimonial entity has sufficient assets to cover its immediate liabilities; the higher is this difference (indicator value), the more favorable is the situation of the entity in the respective domain. It is known that a satisfactory working capital represents an element of attraction for potential customers of banks and commercial creditors, and firms with inadequate trading capital will be at risk of not being able to obtain loans. Note however that property assets of entities will vary both in value and in terms of liquidity, with influence over the company's ability to meet its obligations in the short term.

It is an expression of short-term financial balance and reflects the ability of available current assets to transform into cash to cover short-term due date debts. If it has subunit values indicates an imbalance in the company treasury level.

Financial safety interval: $150 \%-250 \%$.

Immediate liquidity rate (intermediate) - Acid Test (Current assets - Inventories) / Short term debts $x$ 100)

It reflects the ability of current assets of the company, resulting in receivables and treasury to honor short-term exigible debts. Immediate liquidity removes inventories from the calculation.

Financial safety interval: 50\% $-100 \%$.

Restricted liquidity rate (Cash + Securities / Short term debts)

Restricted liquidity eliminates the stocks as well as the receivables-customers.

Financial safety interval: if the restricted liquidity exceeds level 1.0, then the patrimonial entity has an excellent short term solvency. 100)

Effective liquidity rate (Treasury / Short term debts $x$ It reflects the Company's ability to meet short-term obligations based on cash and short-term financial investments.

Financial safety interval: $50 \%-100 \%$.

Receivables turnover (Net sales / Average value of gross debt)

Average inventory turnover (Cost of goods sold / Average inventory value)

The two turnover indicators - for receivables and inventories - are very useful in financial audit. Often, the evolution tendency of receivables - customers is used to evaluate the reasonableness of the provisions regarding doubtful debts.

The evolution tendency of inventory turnover rate is used to identify a possible inventory obsolescence problem.

Average duration of cashing the receivables (Gross receivables average value $x 360$ / Net sales)

Average duration of sales (Average value of inventories $x 360$ / Cost of goods sold)

Average duration of transforming inventories into cash (Average duration of sales + Average duration of cashing)

Use of net value of sales from the financial statements in the calculation of debts quality indicators can be problematic if a large part of sales is paid immediately. This issue will be somehow compensated when the proportions are relatively constant in terms of accounting or patrimonial entities for which comparisons are made.

\subsection{Profitability rates:} $x$ 100)

Economic profitability rate (Gross profit / total assets 
It expresses the efficiency of using the assets, namely their contribution to obtain the results.

Financial safety interval: minimization.

Assets profitability rate - ROA (Net Profit / Total Assets $x$ 100)

It expresses the efficiency of using the company's assets in operational activity, namely the profitability degree of the entire capital invested in the company.

Financial safety interval: maximization.

Financial profitability rate (Net profit / Equity x 100) It reflects the efficiency of using the capital invested by shareholders.

Financial safety interval: maximization. 100)

Overall profitability rate (Net profit / Total expenses $x$

It expresses the total consumption of resources. Financial safety interval: maximization.

\subsection{Market rates:}

Share accounting value - its intrinsic value (Equity / No. of issued shares)

It reflects the net asset value per share, namely the amount that would be cashed by a shareholder from selling the company's shares and honoring the debts to creditors.

Financial safety interval: maximization.

Price rate - accounting value $\mathrm{P} / \mathrm{B}$ - market value rate (Share exchange rate / share accounting value)

The indicator compares the market value of a share to its accounting value. In case of a subunit report, it is considered that the share is overvalued, generating a purchase signal for investors. In case in which the exchange rate exceeds the accounting value, the share is overvalued and the investor receives a selling signal. Financial safety interval: not applicable.

Earnings per EPS share (Net profit / Number of common issued shares)

It expresses the internal efficiency of a share, in terms of profit that the share brings in a financial year and allows the investor to compare the results obtained by the firm to decide whether liquidates or increases the share package held.

Financial safety interval: maximization.

Capitalization coefficient of PER stock- the coefficient of capitalization (share exchange rate / earnings per share)

It expresses market turnover of a share, in terms of the amount an investor is willing to pay to obtain a monetary unit from the company's profit. It also indicates the necessary period of a shareholder to recover the capital invested. The indicator represents a measure of the investor's confidence in the company, meaning that a higher value indicates a higher level of expectation from the evolution of firm's profits. The values of this indicator should be interpreted in the context of companies which operates in similar fields of activity. The lower the PER $i s$, the more interesting a share is considered, being recommend to buy and to hold it. However, a low PER may be associated with risky business companies, while firms with good prospects of development can record a high level of PER.
Financial safety interval: minimization.

Shares return (Share dividend / Share exchange rate $x$ 100). The indicator represents a measure of the earnings obtained by the shareholders, the investment made in the company's shares by reporting income brought by the shares to its cost. Investors use this indicator to compare income from investments in shares within the same sector or of different market sectors, as well as income from investments in other financial instruments - interest on investments in fixed income instruments. This indicator does not necessarily express the performance of a company, especially those that increase, pursuing a policy of capitalization of the obtained profit.

Financial safety interval: maximization.

Dividends distribution rate (Share dividend / Earnings per share $x$ 100)

A low level of this indicator brings dissatisfaction o the shareholders, reflecting a policy of reinvestment of profits at the expense of dividends distribution. Financial safety interval: not applicable.

\subsection{Other indicators:}

Efficiency (Net Sales / Operating tangible assets) The indicator shows the relative volume of activity generated by the basic operational patrimonial assets of a patrimonial entity. The indicator shows whether there is generated enough revenue to justify the assets volume used. When the efficiency rate is low, it could mean that before purchasing additional assets should aim to achieve a higher production volume. If the indicator has a big value, this could indicate that the assets are close to the end of their useful life and that soon maturity will come for a new investment in new assets.

Gross margin in relative size (Net sales - Cost of goods sold / Net sales).

The indicator represents the proportion in which the revenues from sales exceed the variable costs (expenses). When the indicator has a low value, it indicates a high level of manufacturing cost of products compared to sales prices.

Profit margin (Operating profit / Net sales)

Through this indicator is presented the proportion with which the sales exceed the costs (both variable and fixed ones). An unacceptable level of the indicator value means that gross margins (revenues in excess to the variable costs) has a low level or that the production volume is far below the fixed expenses.

Return on equity (Profit before taxes - Preferred dividends /(1 - Tax rate) / Share capital)

If the indicator is inferior to the long-term basis rate of interest or rate of return of alternative investments, the owners will consider that should guide the patrimonial entity's assets in another direction of use or even to liquidate the company if the return cannot be improved.

Profit-turnover ratio (Profit / Turnover) It expresses the contribution of turnover to obtain profit. Financial safety interval: maximization.

Interest coverage degree (Operating profit / Expenses on interest)

The capacity to deal with the interest payment obligations are preferred a function of the patrimonial 
entity's ability to generate a positive cash flow from operations both in the short term as well as in the future. Thus, interest coverage degree shows how stable is the patrimonial entity's ability to honor its interest payment obligations, assuming that the benefits remain constant.

- Substantial operating losses or significant deterioration in the value of assets used to generate cash flows;

- Debts or discontinuance of paying the dividends;

- Inability to pay creditors on due dates;

In case a patrimonial entity meets difficulties in securing cash and monetary equivalents to meet the obligations incurred, its solution of solvency will be the time margin required for conversion of current assets less liquid into cash. Short term liquidity indicators are the solution of determining the extent to which such operations can be achieved.

- Failure to comply with the terms of credit contracts; As a general rule, creditors are concerned about a company's ability to meet its obligations to pay interest and repay the loan. This capacity will be estimated by evaluating the long-term prospects of the patrimonial entity and the situation of its net assets. The feasible value of the assets will be important and may refer to specific assets to ensure debts incurred.

- Change from transactions with suppliers based on credit at transactions with payment at delivery;

- Inability to obtain financing for essential new product development or other essential investments;

- Operational indicators that can predict events or conditions which might cast doubt on the going concern assumption

- Other indicators which can predict events or conditions that cast doubt on the going concern assumption

\section{CONCLUSIONS}

On one hand when presenting information in the form of financial statements, the financial audit's beneficiary makes several assertions about its financial condition and with the results of its activities. On the other hand, external users who rely on these financial statements to make economic decisions refer to the auditor's report as an indicator of reliability situations. They value the insurance provided by the auditor due to the client's independence and because of his knowledge in financial reporting domain.

There are significant legal precedents suggesting that management is responsible for providing reliable information to users. If users are based on inaccurate financial statements and as a result, recorded a financial loss, they can sue the management of the patrimonial entity concerned. One of the difficulties of sharing the information risk with the management is the likelihood that users will not be able to recover losses. If a firm is unable to repay a loan because of bankruptcy, management is unlikely to have sufficient funds to compensate the users' information.

Auditors often face situations in which occur simultaneously several conditions requiring a deviation from unqualified report or a modification of the standard unqualified report. In these circumstances, the auditor should modify its opinion to reflect each condition, except in case in which one of the conditions is neutralizing all others. One of the modifications would circumscribe the existence of substantial doubt regarding the patrimonial entity's ability to continue its activity and at the same time, information regarding the uncertainties causes are not adequately disclosed in an informative note.

The key to solving the most complex financial problems remains improving operational activity (operation). Both creditors and investors are interested in the results of operations of a patrimonial entity and there is not surprising that it is used a large number of benchmarks from operating activities and results of firms. Perhaps the most widely used operating performance indicator is profit per share, which is an integral part of the financial statements of most patrimonial entities.

It should be taken into account other additional indicators that will contribute to the true and fair view of the financial analysis perspective of the company's operating activities.

Usefulness of these indicators for comparisons in time or between firms may be affected by the classification of certain items in operational or nonoperational role, stock assessment methods, the method of depreciation of fixed assets, amortization of goodwill, research and development expenses and off-balance sheet financing.

Selection of indicators presented in this paper aims to promote a new approach using analytical procedures applied by auditors, primary concern to anticipate future events and to give guarantees on going concern of the firm. At these groups of indicators and not only for reasons of efficiency in determination, it can assign points; it can conceive prioritization and relevance levels.

\section{REFERENCES}

[1] Fratzscher Marcel, Capital flows, push versus pull Factors and the Global Financial Crisis, European Central Bank Working Paper Series, July, 2011

[2] Helfert Erich, Techniques of Financial Analysis, a guide to value creation, McGraw Hill Companies, Inc., New York, 2004

[3] Loebbecke Arens, Audit. An Integrated Approach, 8th Edition, ARC Publishing House, 2003

[4] Schuknecht Ludger, Moutot Philippe, Rother Philipp and Stark Jürgen, The Stability and Growth Pact. Crisis and Reform, European Central Bank, Occasional Paper Series, September 2011

[5] Federation of Accountants - I.F.A.C., Handbook of International Standards on Auditing and Quality Control, IRECSON Publishing House, Bucharest, 2009

[6] International Accounting Standards Committee Foundation I.A.S.C.F., International Financial Reporting Standards, IASC Foundation Publications Department, London, 2009

[7] http://ro.scribd.com/doc/38873624/Analyze-Diagnosis-ofEnterprises

[8] http://www.contabilii.ro/index.php?option=com_content\&view=art icle\&id=2655: indicators-financial-key-in-assessment-of-acompany\&catid=145: situations-financial-balance-sheet2010\&Itemid $=185$ 